\title{
Rock magnetic study of fluvial Holocene soil from Buenos Aires province (Argentina)
}

\author{
Carlos A. Vasquez ${ }^{1,2}$ and Hugo G. Nami ${ }^{2,3}$ \\ ${ }^{1}$ Ciclo Básico Común, Universidad de Buenos Aires.Ciudad Universitaria (Pabellón III), (1428) Buenos Aires, Argentina \\ ${ }^{2}$ CONICET_Instituto de Geofísica "Daniel A. Valencio", Departamento de Ciencias Geológicas, Facultad de Ciencias Exactas, \\ Físicas y Naturales, Universidad de Buenos Aires, Ciudad Universitaria (Pabellón II), (1428) Buenos Aires, Argentina \\ ${ }^{3}$ Associate Researcher, Deparment of Anthropology, National Museum of Natural History, \\ Smithsonian Institution, Washington D.C., 20560, U.S.A.
}

(Received December 22, 2005; Revised June 4, 2006; Accepted June 5, 2006; Online published November 8, 2006)

\begin{abstract}
The magnetic characteristics of soils are widely used in environmental and paleoclimatic investigations for studying the several factors involved in the soil formation process. We propose here a new analytical tool that takes into account the variations in magnetic properties correlated with grain sizes and concentrations of ferrimagnetic minerals. This analytical tool is based on a mathematical model of well-established magnetic properties in samples of known grain sizes and was used in this study to determine changes in the grain size and concentration of ferrimagnetic minerals along a terminal Pleistocene/Holocene fluvial section located in the northeast of Buenos Aires province. These variations may reflect a humid period prevailing in the area and may be associated with climate changes that occurred in the Chaco-Pampean region during the Middle Holocene.
\end{abstract}

Key words: Rock magnetism, Magnetite, Titanomagnetite, Holocene, Buenos Aires.

\section{Introduction}

The magnetic characteristics of soils are widely used as defining parameters in environmental and paleoclimatic studies (Orgeira et al., 1998, 2003; Jordanova and Jordanova, 1999; Petrovsky et al., 2001; Thomson et al., 2001). Several climatic and environmental factors have been identified as contributing to the magnetic signal of soils, including temperature, humidity, winds, floods, rivers, and ground water table, among others (Verosub and Roberts, 1995; Maher and Thompson, 1999). More specifically, temperature and humidity can be associated with the pedogenetic process involved in the production of SP (superparamagnetic) or SP/SSD (stable single-domain) boundary particles (Dearing et al., 1996; Jordanova and Jordanova, 1999), while winds and rivers are related to the transport process of detritic magnetic particles. In this case, grain size ranges between those of PSD (pseudo single-domain) and MD (multi-domain) boundary particles (Evans, 2001; Matasova et al., 2001). The influence of the ground water table is more complex because magnetite is formed in this interface (MacBride, 1994), and changes in $\mathrm{pH}$ and redox can dissolve the magnetite grains (Jordanova and Jordanova, 1999).

In soils formed from wind parental material, such as loess-paleosoil sequences, the magnetic signal results from two opposite formation processes-wind transport and pedogenesis - with the balance between the two being determined by the distance from the parental detritic material

Copyright (c) The Society of Geomagnetism and Earth, Planetary and Space Sciences (SGEPSS); The Seismological Society of Japan; The Volcanological Society of Japan; The Geodetic Society of Japan; The Japanese Society for Planetary Sciences; TERRAPUB source (Hunt et al., 1995; Petrovsky et al., 2001; Evans, 2001). Although the (changing) transport mechanism of a river is known to affect the magnetic signal of fluvial material, it is also possible the basis of this association lies in the fluvial parental material (Jordanova et al., 1997).

The aim of this investigation reported here was to estimate the grain sizes and concentrations of ferrimagnetic minerals in a fluvial section located in Buenos Aires province (Argentina), based on a mathematical model of well-established magnetic properties of samples of known grain size (Dunlop and Özdemir, 1997).

\section{Sampling Site and Chronological Considera- tions}

The Lomas del Mirador (LM; 34³9.29’ S, 58 $32.17^{\prime} \mathrm{W}$ ) site is located in the outskirts of Buenos Aires City (Fig. 1). From a geomorphological and geological viewpoint, Buenos Aires belongs to the Chaco-Pampean region (Russo et al., 1979). There is to date no evidence of fluvial activity at LM, however, the sediments belong to a characteristic floodplain deposit. This area was an active fluvial environment during the terminal Pleistocene/Holocene and also subject to pedogenesis. There is a currently fully developed soil that is suggestive of a period of non-deposition and landscape stability (Holliday 1985; Kraus and Brown 1986). According to Favier Duvois (personal communication), the deposit at LM is similar to the Guerrero member of the Luján formation, which is a useful horizon marker for late Pleistocene and early Holocene sediments (Cione and Tonni 1995; Tonni et al., 1999, 2003).

A $1-\mathrm{m}^{2} \times 2.7-\mathrm{m}$ deep trial pit in the sediment deposit revealed the presence of five stratigraphic levels (I-V; Fig. 2): 
Table 1. List of dates obtained from LM deposit. Depths are given in meters below the surface.

\begin{tabular}{|c|c|c|c|c|c|}
\hline $\begin{array}{c}\text { Material } \\
\text { dated }\end{array}$ & Depth & Method & $\begin{array}{l}\text { Absolute date } \\
\text { (years BP) }\end{array}$ & $\begin{array}{c}\text { Relative minimum } \\
\text { date (years BP) }\end{array}$ & $\begin{array}{c}\text { Identification } \\
\text { number }\end{array}$ \\
\hline Mollusc & $0.60 / 0.70$ & ${ }^{14} \mathrm{C}-\mathrm{AMS}$ & Modern & - & CURL-5502 \\
\hline Mollusc & $1.20-1.25$ & ${ }^{14} \mathrm{C}-\mathrm{AMS}$ & $4900 \pm 110$ & - & OS-24330 \\
\hline Sediment & 0.55 & OCR & - & 115 & Act \# 2943 \\
\hline Sediment & 1.22 & OCR & - & 789 & Act \# 2944 \\
\hline Sediment & 1.55 & OCR & - & 1374 & Act \# 2945 \\
\hline Sediment & 1.88 & OCR & 一 & 3110 & Act \# 2946 \\
\hline Sediment & 2.05 & OCR & - & 4546 & Act \# 2947 \\
\hline Sediment & 2.30 & OCR & - & 5525 & Act \# 3230 \\
\hline Sediment & 2.30 & OCR & - & 6065 & Act \# 3360 \\
\hline Sediment & 2.39 & OCR & - & 6139 & Act \# 3228 \\
\hline Sediment & 2.39 & OCR & 一 & 6609 & Act \# 3362 \\
\hline Sediment & 2.39 & OCR & - & 6836 & Act \# 3234 \\
\hline Sediment & 2.63 & OCR & - & 7165 & Act \# 3363 \\
\hline Sediment & 2.63 & OCR & 一 & 7556 & Act \# 3229 \\
\hline
\end{tabular}

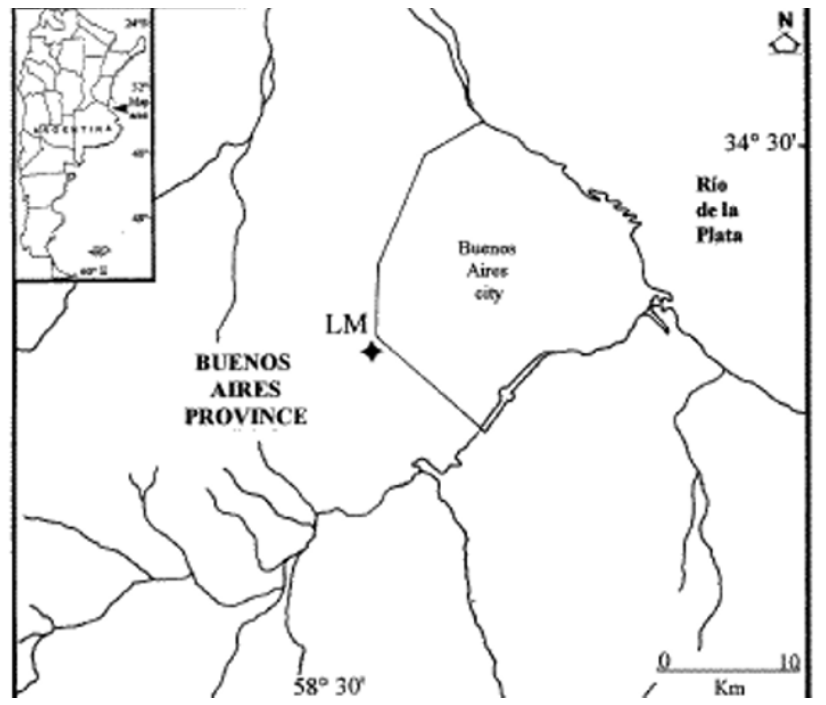

Fig. 1. Location map of the sampling site (LM) in Northeastern Buenos Aires province.

I is an artificial landfill, II is very dark brown $(2 / 2,10 \mathrm{YR}$ Munsel color chart) highly compacted silt sediments, III is a dark-brown $(2.5 / 3,7.5 \mathrm{YR})$ silty clay level, IV is a palebrown $(6 / 3,10 \mathrm{YR})$ silty sand sediment, and $\mathrm{V}$ is a light yellowish brown $(6 / 4,10 \mathrm{YR})$ silty clay deposit with calcareous inclusions. Levels II-IV belong to the same soil formation horizon (Nami, 2006). After the northern profile of the trial pit had been cleaned, approximately 100-g samples $(n=19)$ were collected in nylon bags. Directional analysis was carried out on those levels belonging to the terminal Pleistocene and Holocene (Nami, 2006). Hence, consecutive samples were continuously taken without intervals in levels II-IV between 0.54 and $1.49 \mathrm{~m}$ below the surface.

The age of the deposit was determined using different dating methods. Two ${ }^{14} \mathrm{C}$ dating analyses on shell samples using mass accelerator spectrometry (AMS) revealed that a small piece of unidentified mollusk from level II contains more ${ }^{14} \mathrm{C}$ than the 1950 atmosphere; this sample is therefore "modern"- $<1950 \mathrm{AD}$ - which is coincident with the age of the artificial landfill. ${ }^{14} \mathrm{C}$ dating of a specimen of the

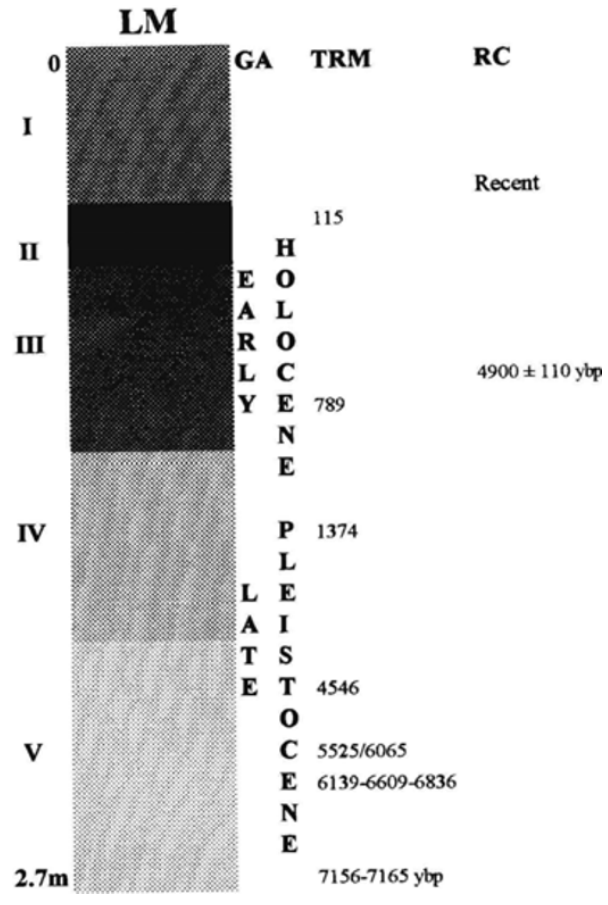

Fig. 2. Lomas del Mirador (LM) Holocene soil profile. GA: Geological Age. TRM: Mean residence time. RC: Radiocarbon age.

micro-faunal mollusk (Mactra isabelleana) belonging to the lower part of level III revealed an age of $4900 \pm 110$ years BP (OS-24330), which is coincident with radiocarbon dates obtained from M. isabelleana collected from other sites in the region (Tonni et al., 1999). This micromollusc is a typical fossil found in Holocene deposits from Buenos Aires (Aguirre, 1988, 1993).

The mean residence time (MRT), of the soil, which is a measure of the mixing of the young organic carbon with organic carbon from earlier stages of pedogenesis (Stein, 1992), was determined employing the oxidizable carbon ratio (OCR) analytical method (Frink, 1992, 1994, 1995; Scharpenseel, 1971). Twelve OCR dates were obtained from levels II-V ranging between 115 and 7556 years BP (0.11-7.55 kybp; Table 1). Taking into account the radiometric date, these dates must be considered as relative mini- 
mum ages. Although there are notably differences between the ${ }^{14} \mathrm{C}$ and OCR dates that are correlated with depth, the latter dates simply confirm that the soil surface was open to organic input for a long period (e.g., Scharpenseel, 1971; Stein, 1992). Our MRT values therefore suggest that the deposit was open to organic material deposition during the last $\sim 8 \mathrm{kyr}$ (i.e. through much of the Holocene), thereby confirming the terminal Pleistocene/Holocene age of the soil formation. In fact, its boundary with the Pleistocene was conventionally established by Dawson (1992) to be $10 \mathrm{kyr}$ BP. In addition, a comparison of the results obtained in other sections from Argentina with the paleomagnetic directions registered at LM suggest that the magnetic signal of the latter belong to the terminal Pleistocene-Holocene (Nami, 2006). To summarize, based on geological, chronological, and paleomagnetic studies it is possible to suggest that the magnetic signal reported in this paper belongs to the Holocene.

\section{The Mathematical Model of Grain Size and Concentration}

Magnetic properties of a soil are correlated with sizes and concentration of the grains in a qualitative manner. While it is difficult to establish a mathematical relationship between grain size and magnetic properties for most minerals (Dunlop and Özdemir, 1997), magnetite PSD grains can be easily modeled. We therefore propose a mathematical model based on well-established data that is applicable to the quantification of grain sizes and their concentrations in natural samples where PSD magnetite drives the magnetic signal.

\subsection{Relationship between $M_{r s} / M_{s}$ and the grain size}

The ratio $M_{r s} / M_{s}$ (specific saturation remanence/specific saturation magnetization) is the higher sensitivity parameter to magnetic grain size of magnetite in the PSD-MD range (Dunlop and Özdemir, 1997; Dunlop, 2002). Both $M_{r s}$ and $M_{s}$ are grain size- and concentration-dependent parameters, but their ratio is a concentration-independent parameter (Banerjee, 1981; Benerjee and Hunt, 1993). The theoretical relationship between the grain diameter $\mathrm{d}$ and the $M_{r s} / M_{s}$ ratio, as proposed by Halgedahl and Fuller (1983) is:

$$
M_{r s} / M_{s}=A * \exp \left(-\left(d / d_{o}\right)^{1 / 2}\right)
$$

where $A$ and $d_{o}$ are constants that are dependent on magnetite or titanomagnetite characteristics (Hartstra, 1982; O’Donovan et al., 1986; Dunlop and Özdemir, 1997; Dunlop, 2002). From this, it is possible to determine the grain size if the $M_{r s} / M_{s}$ ratio is known.

A comparison of Eq. (1) to the experimental data of Hartstra (1982) and O'Donovan et al. (1986) is shown in Fig. 3. This figure reveals the presence of a very good agreement between the data of Hartstra (1982) and the theoretical model, while there is more dispersion between the data of O'Donovan et al. (1986) and the theoretical model, although the fit is still reasonable good. The parameters for the model are:

$$
M_{r s} / M_{s}=A_{o}+A_{1} * \exp \left(-\left(d^{1 / 2}-x_{o}\right) / t_{1}\right)
$$

where $A_{o}=0.0512, A_{1}=.46148, x_{o}=1.41421 \mu m^{1 / 2}$, $t_{1}=1.89716 \mu \mathrm{m}^{-1 / 2}$.

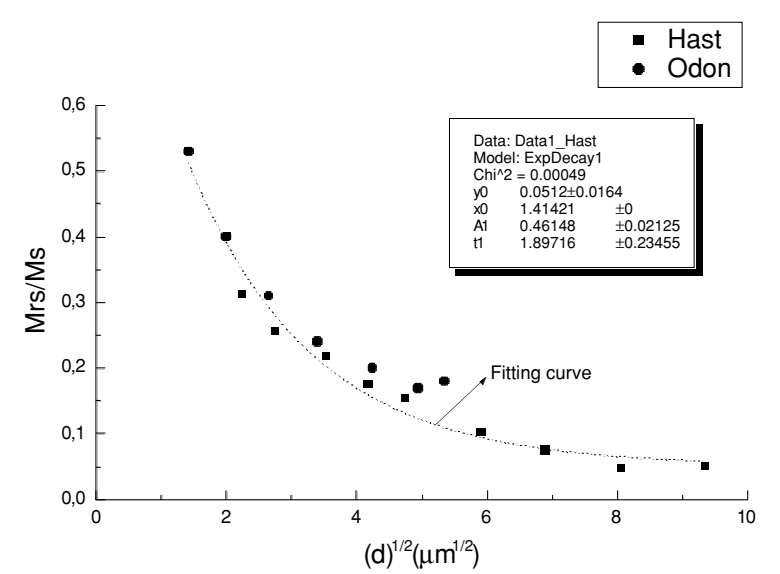

Fig. 3. Fiting of Hastra (1982) and O'Donovan et al. (1986) data of titanomangetites to an exponencial function of $M_{r s} / M_{s}$ vs. square root of diameter.

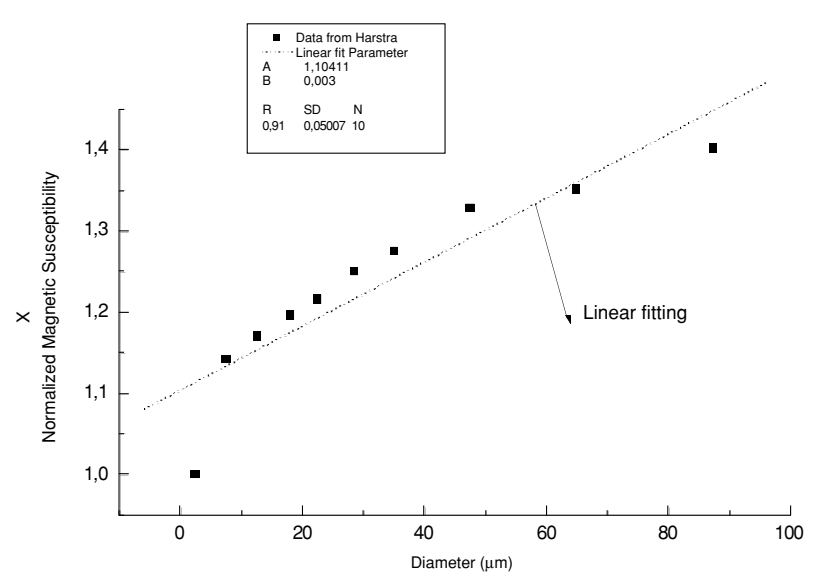

Fig. 4. Linear fit of diameter vs. susceptibility, data from Hastra (198).

Arranging terms in Eq. (2) results in the following:

$$
M_{r s} / M_{s}=A_{o}+A_{1}^{\prime} * \exp \left(-\left(d / t_{1}^{2}\right)^{1 / 2}\right),
$$

where $t_{1}^{2}=d_{o}$, and $A_{1}^{\prime}=A_{1} * \exp \left(x_{o} / t_{1}\right) ; A_{o}$ is an asymptotic term, indicating that the $M_{r s} / M_{s}$ tends towards a constant value when d goes to infinity.

From Eq. (2), it is possible to determine the titamomagnetite grain diameter $d$, according to the expression:

$$
d=\left(x_{o}-t_{1} * \ln \left(\left(M_{r s} / M_{s}-A_{o}\right) / A_{1}\right)\right)^{2}
$$

The model of Halgedahl and Fuller (1983) can be used in sediments where titanomagnetite or magnetite is the main magnetic carrier and the grain diameter ranges between 5 and $100 \mu \mathrm{m}$. Both of these conditions remain valid for the soil under study here where magnetic detritic grains can be transported by rivers or wind (Scasso and Limarino, 1997).

\subsection{Magnetic susceptibility and titanomagnetite con- centration}

Changes in the ferrimagnetic initial magnetic mass susceptibility $\chi$ can be attributed to two main causes: the concentration and grain size of magnetic minerals. At the same grain size, susceptibility $\chi$ is proportional to concentration (Dunlop and Özdemir, 1997). According to Hartstra (1982) and O'Donovan et al. (1986), there is a relationship between 
Table 2. Mass Susceptibility at $470 \mathrm{~Hz}(\mathrm{~K} \mathrm{LF})$, and $4700 \mathrm{~Hz}(\mathrm{~K} \mathrm{HF})$, Coercitive Magnetic Field ( $B_{c}$ ), and Coercitive Remanence Magnetic Field ( $B_{c r}$ ), Remanent Saturation Magnetization $(\mathrm{Mr})$ and Saturation of Magnetization $\left(M_{r s}\right)$ in LM profile.

\begin{tabular}{|c|c|c|c|c|c|c|}
\hline Depth $(\mathrm{cm})$ & $\mathrm{K}\left(\mathrm{m}^{3} / \mathrm{kg}\right) \mathrm{LF}$ & $\mathrm{K}\left(\mathrm{m}^{3} / \mathrm{kg}\right) \mathrm{HF}$ & $B_{c r}(\mathrm{mT})$ & $B_{c}(\mathrm{mT})$ & $M_{r s} /$ masa (1E-8) & $M_{s} /$ masa $(1 \mathrm{E}-8)$ \\
\hline-54 & $1.262 \mathrm{E}-06$ & $1.214 \mathrm{E}-06$ & 29.6 & 10.9 & 16.546875 & 102.34375 \\
\hline-58 & $1.2785 \mathrm{E}-06$ & $1.225 \mathrm{E}-06$ & 29.6 & 10.2 & 15.81481481 & 97.96296296 \\
\hline-63 & $1.452 \mathrm{E}-06$ & $1.386 \mathrm{E}-06$ & 30 & 10.5 & 17.75384615 & 108.9230769 \\
\hline-68 & $1.6069 \mathrm{E}-06$ & $1.532 \mathrm{E}-06$ & 30.2 & 10.58 & 18.22807018 & 113.8596491 \\
\hline-73 & $1.8476 \mathrm{E}-06$ & $1.769 \mathrm{E}-06$ & 32.4 & 10.5 & 22.68292683 & 148.7804878 \\
\hline-78 & $1.9877 \mathrm{E}-06$ & $1.903 \mathrm{E}-06$ & 32.7 & 10.99 & 27.3442623 & 180.442623 \\
\hline-83 & $1.9804 \mathrm{E}-06$ & $1.903 \mathrm{E}-06$ & 33.1 & 10.96 & 27.33962264 & 182.0754717 \\
\hline-88 & $2.0201 \mathrm{E}-06$ & $1.932 \mathrm{E}-06$ & 32.9 & 11.1 & 27.35185185 & 183.4444444 \\
\hline-93 & $2.0641 \mathrm{E}-06$ & $1.978 \mathrm{E}-06$ & 34.1 & 11.7 & 28 & 180.3833333 \\
\hline-98 & $2.0399 \mathrm{E}-06$ & $1.955 \mathrm{E}-06$ & 33.5 & 11.5 & 27.44827586 & 177.5862069 \\
\hline-103 & $1.9789 \mathrm{E}-06$ & $1.903 \mathrm{E}-06$ & 34.5 & 11.79 & 30.03333333 & 196.9 \\
\hline-108 & $1.9864 \mathrm{E}-06$ & $1.913 \mathrm{E}-06$ & 34.3 & 11.57 & 27.3968254 & 181.3174603 \\
\hline-113 & $2.0398 \mathrm{E}-06$ & $1.967 \mathrm{E}-06$ & 33.7 & 11.5 & 31.43396226 & 203.5849057 \\
\hline-118 & $2.0621 \mathrm{E}-06$ & $1.986 \mathrm{E}-06$ & 34.4 & 11.81 & 33.16981132 & 215.7169811 \\
\hline-123 & $1.9817 \mathrm{E}-06$ & $1.906 \mathrm{E}-06$ & 34.7 & 12.2 & 28.57377049 & 186.7213115 \\
\hline-128 & $1.9532 \mathrm{E}-06$ & $1.886 \mathrm{E}-06$ & 34.3 & 11.37 & 27.15789474 & 185.4385965 \\
\hline-133 & $1.933 \mathrm{E}-06$ & $1.885 \mathrm{E}-06$ & 34.6 & 12 & 31.82978723 & 213.1914894 \\
\hline-138 & $1.9301 \mathrm{E}-06$ & $1.89 \mathrm{E}-06$ & 34.4 & 11.53 & 30.33333333 & 206.4509804 \\
\hline-143 & $1.8907 \mathrm{E}-06$ & $1.845 \mathrm{E}-06$ & 34.4 & 11.59 & 28.375 & 190.5178571 \\
\hline-148 & $1.9002 \mathrm{E}-06$ & $1.859 \mathrm{E}-06$ & 34.4 & 11.59 & 28.375 & 190.5178571 \\
\hline
\end{tabular}

grain size and the susceptibility of magnetites and titanomagnetites in the range 5-100 $\mu \mathrm{m}$. Consequently, it is possible to determine a linear correlation between these based on their data, as shown in Fig. 4.

In order to analyze the effect of grain size on susceptibility, a normalized susceptibility is defined:

$$
\chi_{N}(d)=\chi / \chi_{L}
$$

where $\chi_{L}$ is the lowest susceptibility value. The relation between normalized susceptibility $\chi_{N}(d)$, and grain diameter $d$ is then:

$$
\chi_{N}(d)=A+B * d
$$

where the $A$ and $B$ parameters are shown in Fig. 4.

With this susceptibility "corrected" by grain size, it is now possible to determine the magnetic concentration if the magnetic mineralogy is known by independent tests: coercitive magnetic fields $\left(H_{c}\right.$ and $\left.H_{c r}\right), \chi$ vs. temperature curves, and high and low temperatures, among others.

Let $\chi_{N}$ be the normalized susceptibility to the lowest susceptibility by mass unit; $N(d)$, the grain concentration, which is diameter (d)-dependent with a range between 0 and $1 ; \chi_{d}$, the bulk susceptibility from grains of diameter $d$ per mass unit. If all of the grains of the sample have the same diameter and all are magnetic grains, $N=1$, and the normalized bulk susceptibility $\chi_{N}$ is

$$
\begin{aligned}
\chi_{N} & =\int N(d) \dot{\chi}_{N}(d) d d=A \cdot \int N(d) d d \\
& +B \cdot \int N(d) \cdot d d d \approx A \cdot N
\end{aligned}
$$

because the $B$ factor is threefold lower that $A$ and $\int N(d) . d d d$ is acoted ( $0 \leq N(d) \leq 1, d \leq 100$ E-6 m). The bulk normalized susceptibility $\chi_{N}$ is mainly driven by the concentration factor $N$. It is only a rough model that may be used in a semi-quantitative analysis.

\section{Magnetic Analysis and Grain Concentration Determination}

\subsection{Experimental methods}

In the laboratory, sub-samples from the bagged samples were air-dried at room temperature, crushed in agar mortar and mixing several times in order to have representative samples. They were then weighed and packed into plastic boxes $(2.5 \times 2.5 \mathrm{~cm}$; height $\times$ diameter $)$ for magnetic analysis. The remaining portions of the samples were used for non-magnetic treatments.

Magnetic susceptibility was measured in the Bartington MS2 analyzer. A Molspin VSM Nuovo vibrating sampling magnetometer was used to measure the $M_{s}, M_{r s}, B_{c}$ and $B_{c r}$ magnetic parameters at room temperature. Measurements at high temperatures were carried out using a Bartington MS2W susceptibilimeter.

\subsection{Results}

Thermomagnetic analysis, hysteresis cycles, and IRM were carried out. The thermomagnetic curves are shown in Fig. 5. and the hysteresis and IRM parameters are shown in Table 2. The thermomagnetic curves show that the susceptibility is near constant, in the low temperature zone, without any Verwey transition. On the other hand, the high temperature zone shows a peak near $500 \mathrm{~K}$, after which the curve is very similar to that of magnetite, with a marked drop near the magnetite Curie point (approx. $850 \mathrm{~K}$ ). The susceptibility curve does not show the characteristic Hopkinson peak of SSD magnetite near the Curie point (Dunlop and Özdemir, 1997). These two results together with the flat curve at the low temperature are in agreement with a partial oxidation of magnetite (Dunlop and Özdemir, 1997; Thompson et al., 2001; Carter-Stiglitz, 2002).

The susceptibility and hysteresis parameters of 19 levels in the LM section are shown in Table 2. The $\chi$ percentage difference in susceptibility at low and high frequencies is lower than $2 \%$, indicating that the SP fraction is very low. This result is in agreement with the detritic origin of magnetic minerals because under anoxic conditions a pedoge- 
(a)
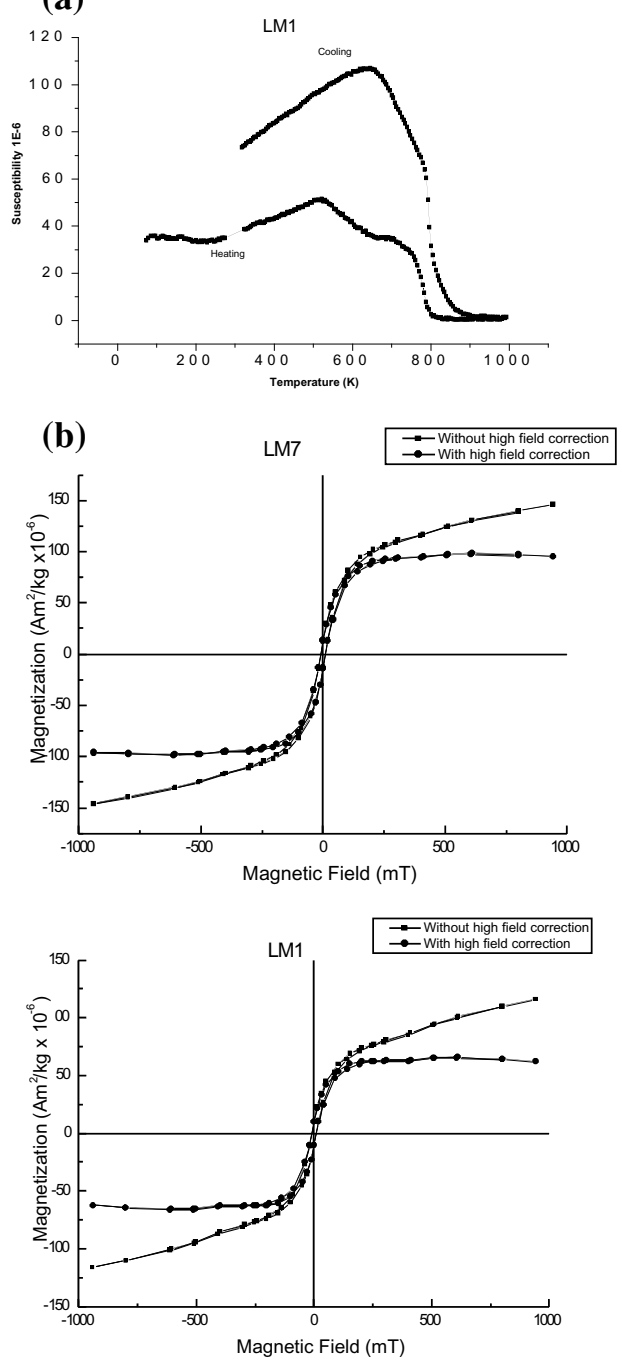

(c)

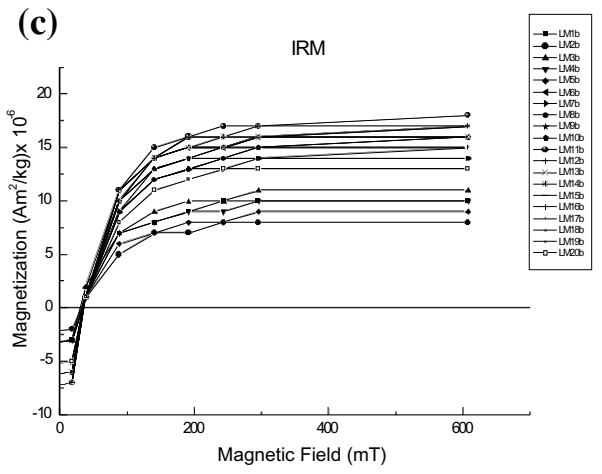

Fig. 5. (a) Heating and cooling susceptibility in air of LM1 sample. The Verwey transition is not present in the low temperature section. It is indicative of oxid magnetite as the main magnetic carrier. Mineralogical transformation of titano-magnetite to magnetite is shown as a drop in heating curve at $850 \mathrm{~K}$, near the Curie point. (b) Hysteresis loops from two representatives samples, LM1 and LM7. (c) Isothermal Remanent Magnetization curves from all the samples. An initial magnetization at $800 \mathrm{mT}$ is given and after a reverse magnetic field is applied.

netic neoformation of SP magnetite would occur (Petrovsky et al., 2001).

The median values of $B_{c r}$ and $B_{c}$ ( \pm standard error) shown in Table 3 are in agreement with a homogeneous magnetic mineralogy of similar grain size. The results pre-
Table 3. Media value and Standard Error of Media for the magnetic parameters displayed in Table 1.

\begin{tabular}{ccc}
\hline $\begin{array}{c}\text { Magnetic Parameter } \\
\text { (units as in Table1) }\end{array}$ & Media Value & $\begin{array}{c}\text { Standard Error } \\
\text { of Media }\end{array}$ \\
\hline$B_{c r}$ & 33.09 & 0.40111 \\
$B_{c}$ & 11.294 & 0.1231 \\
$M_{r s}$ & 26.25946 & 1.16286 \\
$M_{s}$ & 172.30797 & 8.3062 \\
KLF & $1.85977 \mathrm{E}-6$ & $5.61095 \mathrm{E}-8$ \\
KHF & $1.79186 \mathrm{E}-6$ & $5.46878 \mathrm{E}-8$ \\
\hline
\end{tabular}

Table 4. Magnetic properties of several magnetic minerals. References: 1) Harstra (1982), 2) O’Donovan and colleagues (1986)

\begin{tabular}{|c|c|c|c|c|c|}
\hline \multirow[t]{2}{*}{ Substance } & \multirow{2}{*}{$\begin{array}{c}\chi\left(\mathrm{m}^{3} / \mathrm{kg}\right) \\
1 \mathrm{E}-6\end{array}$} & \multirow{2}{*}{\multicolumn{2}{|c|}{$\begin{array}{cc}M_{r s} & M_{s} \\
\left(\mathrm{Am}^{2} / \mathrm{kg}\right)\left(\mathrm{Am}^{2} / \mathrm{kg}\right.\end{array}$}} & \multirow{2}{*}{$\begin{array}{c}B_{c r} \quad B_{c} \\
(\mathrm{mT})(\mathrm{mT})\end{array}$} & \multirow{2}{*}{ Ref. } \\
\hline & & & & & \\
\hline Magnetite (sintetic) & 0.824 & 0.028 & 0.16 & 25.712 .3 & 2 \\
\hline Maghemite (sintetic) & 0.544 & 0.029 & 0.106 & 27.315 .4 & 2 \\
\hline Magnetite (natural) & 0.58 & 0.018 & 0.121 & 32.112 .8 & 2 \\
\hline Titanomaghemite (natural) & 0.198 & 0.018 & 0.07 & 53.424 .8 & 2 \\
\hline Magnetite $150-250 \mu \mathrm{m}$ & 601.9 & 0.9 & & 25 & 1 \\
\hline Magnetite $25-30 \mu \mathrm{m}$ & 686.12 & 2.31 & & 33 & 1 \\
\hline Magnetite 5-10 $\mu \mathrm{m}$ & 529.04 & 11.07 & & 54 & 1 \\
\hline Titanomagnetite $25-30 \mu \mathrm{m}$ & 284 & 0.84 & & 8.5 & 1 \\
\hline Titanomagnetite 5-10 $\mu \mathrm{m}$ & 196 & 1.74 & & 11.5 & 1 \\
\hline Maghemite $25-30 \mu \mathrm{m}$ & 361.91 & 3.74 & & 31 & 1 \\
\hline Maghemite $5-10 \mu \mathrm{m}$ & 317.93 & 3.8 & & 37 & 1 \\
\hline Hematite $150-250 \mu \mathrm{m}$ & 1.277 & 0.215 & & 59 & 1 \\
\hline Hematite $25-30 \mu \mathrm{m}$ & 1.576 & 0.234 & & 72.5 & 1 \\
\hline Hematite $10-15 \mu \mathrm{m}$ & 1.178 & 0.231 & & 140 & 1 \\
\hline
\end{tabular}

sented in Table 4 indicate that that choice of natural magnetite grain sizes falls in the range $25-30 \mu \mathrm{m}$.

The standard median error shown in Table 3 is nearly threefold higher for $M_{s}, M_{r s}$, and $\mathrm{K}$ than for $B_{c r}$ and $B_{c}$. However, as $B_{c r}$ shows a $13 \%$ change along the profile and $B_{c}$, a $9 \%$ change, these parameters can be related to minor increases in the grain sizes of the magnetite. The changes in $M_{r s}$ is $42 \%$, in $M_{s} 46 \%$, for both $\mathrm{K} 34 \%$, indicating that variations in these magnetic grain concentration parameters are larger than those of magnetic grain size $\left(B_{c}\right.$ and $\left.B_{c r}\right)$ and that they control the magnetic signature in these sediments.

Figure 6(a) illustrates the semi-quantitative model application along the LM profile, depicting oscillations around $70 \mathrm{~cm}$ and between $90 \mathrm{~cm}$ and $103 \mathrm{~cm}$. However, the general trend is an increase of grain size from the surface downwards. This is in agreement with the proposed transport model, where flooding events can be related to oscillations in grain size.

Based on the experimental data variations in the concentrations of magnetic minerals are influenced by grain size. The mathematical model applied to this soil (Fig. 6(a)) can be used in order to "clean" the magnetic record and to extract the signal based on concentration only. A simple inspection of the plot of the concentration parameters $M_{r s}$, $M_{s}$, and $\chi$ (Fig. 6(b)) does not reveal minor changes in concentration because they are also grain size-dependent. A comparison of Fig. 6(a) and (b) shows a peak near $-90 \mathrm{~cm}$ (Fig. 6(a)) that can be attributed to a flooding event. On the other hand, the grain size is nearly constant along the 


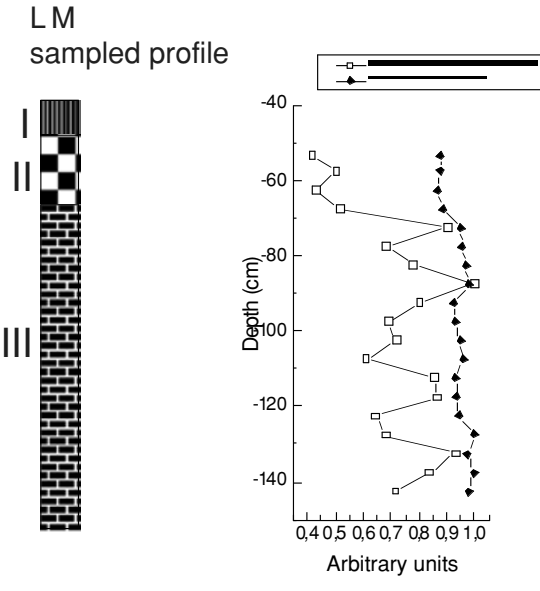

(a)

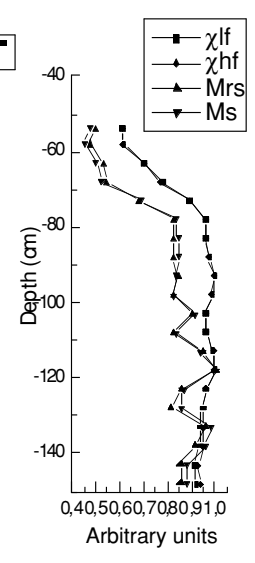

( b )

Fig. 6. (a) Normalized grain concentration and grain size changes with depth. Variations in grain size are lower than grain concentration. (b) Normalized concentration parameters: High and low frequency susceptibility $\chi h f$ and $\chi l f$, magnetization of saturation $M_{s}$, and magnetization remanent of saturation $M_{r s}$.

sampled profile.

\section{Discussion and conclusion}

Based on data from a previous analysis, the magnetic concentration parameters $\left(M_{r s}, M_{s}\right.$ and $\left.\chi\right)$ reveal that there are different zones that might be related with climate changes. In fluvial deposits the magnetic signal and climate are very likely to be associated through environmental changes that modify the fluvial transport (Jordanova et al., 1997). In flood basin deposits, fine-grained sediments include detritic magnetic grains transported as suspension material, with a silt-clay layer 1 or $2 \mathrm{~cm}$ in thickness usually being deposited during one flood period (Reinick and Sing, 1975). The magnetic concentration in the lower part of the LM section $(-0.78$ to $-1.49 \mathrm{~m})$ was found to be higher than that in the upper part $(-0.54 \mathrm{~m}$ to $-0.779 \mathrm{~m})$, indicating that the higher concentration of magnetic minerals in the latter might be related with past humid periods when there was a higher frequency of flooding. The concentration peaks of the four grain types observed in Fig. 6(a) may be related with variations that correspond to four flooding events of different intensity. In this context, diverse lines of paleoenvironmental investigations suggest that during the Holocene the Chaco-Pampean region was characterized by increases in both temperature and precipitation, with a few general departures from these general trends. The period spanning $\sim 8.5-3.5$ kybp consisted primarily of a humid subtropical and tropical climate, with Brazilian fauna characterized by pedogenesis and fluvial dynamics (Iriondo and García, 1993). Although there is no consensus on the subject of climate (see Tonni et al., 1999), between $\sim 7.5-$ 5 kybp the spectrum of mammals reflect a humid climate (Prado and Alberdi, 1999). Most scholars currently agree that there was a climate change in Buenos Aires province during 5 kybp (Iriondo and García, 1993; Iriondo, 1995; Prieto, 1996; Prado and Alberdi, 1999; among others) and that a humid regime may have existed at the time of the Holocene marine transgression during a period of high sea level at 5-6 kybp (Isla, 1989). This phenomenon has been reported to have occurred in several places along the cost of the Buenos Aires province (see Weiler, 1994; Pirazzoli, 1996).

In the ancient fluvial system of Buenos Aires city and the surrounding areas, LM is located in the basin of the Maldonado creek, the main water course that exists in the region. Maldonado creek and the Riachuelo-Matanzas River were two significant affluents of the Río de la Plata (Castellanos, 1975), which is a great mass of water that has been suffering significant variations in its geomorphologic configuration since the Late Pleistocene and Holocene. A regional study performed at the Río de la Plata obtained a curve of relative sea level variation during the Holocene that indicated that these changes have produced important modifications in the distribution of submerged and emerged lands (Cavalotto et al., 1995). Based on these results, Cavallotto et al. (1995) concluded that (1) the maximum high stand of sea level at $6 \mathrm{kybp}$ was at an altitude of $+6.5 \mathrm{~m}$; (2) between 5-3.5 kybp there was a period of stability with no major variation at $+5 \mathrm{~m}$; (3) between 3.5 and $2.9 \mathrm{kybp}$ the sea level rapidly fall to $2.5 \mathrm{~m}$. The Río de la Plata was therefore higher during the middle Holocene than it is at the present time, and a more dynamic drainage system was present at LM. In support of this hypothesis, a marine ingression was dated at $\sim 4-5$ kybp at about $10 \mathrm{~km}$ south of this site in the Riachuelo-Matanzas river basin at Ezeiza (Di Micco, 1990).

In summary, the LM section may be considered to be a soil deposit formed during the Holocene. The magnetic signal showed changes that are to a certain degree correlated with the variations in geology and climate that occurred during the middle Holocene. Consequently, this signal any reflect the humid period prevailing in the region and be representative of the environmental variability existing in northeastern Buenos Aires province during that period. We have shown here that environmental magnetic research is a useful analytical tool for studying issues on climate variability that occurred in the Chaco-Pampean region during more recent geological times.

Acknowledgments. We are indebted to: the University of Buenos Aires and CONICET for their support; Marcia Ernesto (IAG, University of Sao Paulo) for allowing the authors to use their facilities and instruments; the NSF and IAI program for Latin American Quaternary research to global change studies, for providing the AMS dating. The AMS measurement and age calculations were performed by the NOSAMS facility at the Woods Hole Oceanographic Institute and the CU-Boulder INSTAAR Laboratory for AMS Radiocarbon; all other preparations of the samples were performed by the CU-Boulder INSTAAR Laboratory for AMS Radiocarbon Preparation and Research (University of Colorado at Boulder). H. Morrás and C. Favier-Duvois kindly observed the LM soil section; M. Cuadrado Woroszylo was very helpful during the sampling and the editing of this paper.

\section{References}

Aguirre, M. L., Moluscos bentónicos marinos del Pleistoceno-Holoceno en el NE de la provincia de Buenos Aires. PhD thesis, Facultad de Ciencias Naturales y Museo, UNLP, La Plata, 1988.

Aguirre, M. L., Paleobiography of the Holocene molluscan fauna from Northeastern Buenos Aires Province. Argentina: its relation to coastal evolution and sea level changes, Paleogeograph. Palaeoclimatol. Palaecol., 102, 1-26, 1993. 
Banerjee, S. K., Experimental Methods of Rock Magnetism and Paleomagnetism, Advances in Geophysics 23, pp. 25-99, Academic Press, New York, 1981.

Banerjee, S. K. and C. P. Hunt, Separation of local signals from the regional paleomonsoon record of the Chinese Loess Plateau: A rockmagnetic approach, Geophys. Res. Lett., 20, 843, 1993.

Carter-Stiglitz, B., M. Jackson, and B. Moskowitz, Low-temperature remanence in stable single domain magnetite, Geophys. Res. Lett., 29, 1029-1033, 2002.

Castellanos, A., Cuenca Potamográfica del Río de la Plata, in Geografía de la República Argentina. Hidrografía. VII, $2^{\circ}$ parte, pp. 1-159, Sociedad Argentina de Estudios Geográficos, Buenos Aires, 1975.

Cavallotto, J. L., G. Parker, and R. A. Violante, Relative sea level changes in the Río de la Plata during the Holocene. Late Quaternary coastal records of rapid changes: Application to present and future conditions. IInd Annual Meeting (IGCP 367). Abstracts, pp. 19-20, Antofagasta, 1995.

Cione, A. L. and E. P. Tonni, Bioestratigrafía y cronología del Cenozoico Superior de la región Pampeana, in Evolución Biológica y Climática de la región Pampeana durante los últimos cinco millones de años, edited by M. T. Alberdi, G. Leone and E. P. Tonni, pp. 49-74, Museo Nacional de Ciencias Natural-Consejo Superior de Investigaciones Científicas, Madrid, 1995.

Dawson, A. G., Ice Age Earth. Late Quaternary Geology and Climate, Routledge, New York, 1992.

Dearing, J. A., R. J. L. Dann, K. Hay, J. A. Lees, P. J. Loveland, B. A. Maher, and K. O'Grady, Frequency-dependent susceptibility measurements of environmental materials, Geophys. J. Int., 124, 228-240, 1996.

Di Mico, M. M., Estudio de los depósitos pertenecientes al Pleistoceno tardío y Holoceno, presentes en la zona de Ezeiza, partido de Esteban Echeverría, provincia de Buenos Aires, Licentiate thesis, Facultad de Ciencias Exactas, Físicas y Naturales (UBA), 105 pp., Buenos Aires, 1990.

Dunlop, D., Theory and application of the Day plot $\left(M_{r s} / M_{s}\right.$ versus $\left.H_{c r} / H_{c}\right)$. 1. Theoretical curves and tests using titanomagnetite data, $J$. Geophys. Res., 107, 10.1029. EPM 4-1, 2002.

Dunlop, D. J. and Özdemir, Ö., Rock Magnetism. Fundamental and Frontiers, Cambridge University Press, Cambridge, 1997.

Evans, M. E., Magnetoclimatology of aeolian sediments, Geophys. J. Int., 144, 495-497, 2001.

Frink, D. S., The Chemical variability of carbonized organic matter through time, Archaeol. East North Am., 20, 67-79, 1992.

Frink, D. S., The oxidizable carbon ration (OCR): A proposed solution to some of the problems encountered with radiocarbon data, North Am. Archael., 15, 17-29, 1994.

Frink, D. S., Application of the Oxidizable Carbon Ratio Dating Procedure and its Implications for Pedogenic Research, in Pedological Perspectives in Archeological Research, pp. 95-106, Soil Science Society of America, Special Publication 44, Madison, 1995.

Halgedahl, S. and M. Fuller, The dependence of magnetic domain structure upon magnetization state with emphasis upon nucleation as a mechanism for pseudo-single-domain behavior, J. Geophys. Res., 88, 65056522, 1983.

Hartstra, R. L., A comparative study of the ARM and $\mathrm{I}_{s r}$ of some natural magnetites of MD and PSD grain size, Geophys. J. Roy. Astronom. Soc., 71, 497-518, 1982.

Holliday, V. T., Archaeological geology of the Lubbock Lake site, Southern High Plains of Texas, Geol. Soc. Am. Bull., 96, 1483-1492, 1985.

Hunt, P. C., S. K. Banerjee, J. Han, P. A. Solheid, E. Oches, W. Sun, and T. Liu, Rock-magnetic proxies of climate change in the loess-palaeosol sequences of the western Loess Plateau of China, Geophys. J. Int., 123, 232-244, 1995.

Iriondo, M. H., La Pampa. Climas Cuaternarios en América del Sur, In: Argollo, J. and Mourguiart, P. (eds.), Quaternary Climates of South America, Project IGCP 281, ORSTON, Institute Français de Recherce Scientifique pour le Développment en Coopèration, La Paz, 1995.

Iriondo, M. H. and N. O. García, Climatic variation in the Argentine plains during the last 18,000 years, Paleogeograph. Palaeoclimatol. Palaecol., 101, 209-220, 1993.

Isla, F. I., Holocene Sea-Level fluctuation in the southern hemisphere, Quat. Sci. Rev., 8, 359-368, 1989.

Jordanova, D. and N. Jordanova, Magnetic characteristics of different soils types from Bulgaria, Stud. Geophys. Geod., 43, 303-308, 1999.

Jordanova, D., E. Petrovsky, N. Jordanova, J. Evlogiev, and V. Butchvarova, Rock magnetic properties of recent soils from northeastern Bulgaria, Geophys. J. Int., 128, 474-488, 1997.
Kraus, M. and T. M. Brown, Paleosoils and time resolution in alluvial stratigraphy, Paleosoil: Their Recognition and Interpretation, edited by W. P. Wright, pp. 180-207, Princeton University Press, Princeton, 1986.

MacBride, B., Environmental Chemistry of Soils, Oxford University Press, Oxford, 1994.

Maher, B. A. and R. Thompson, Quaternary Climates, Environments and Magnetism, Cambridge University Press, 1999.

Matasova, G., E. Petrovský, N. Jordanota, V. Zykina, and A. Kapitcka, Magnetic study of Late Pleistocene loess/palaeosol sections from Liberia: palaeoenvironmental implications, Geophys. J. Int., 147, 367380, 2001.

Nami, H. G., Preliminary Palaeomagnetic results of a terminal Pleistocene/Holocene record from northeastern Buenos Aires province (Argentina), Geofizika, 2004 (in press).

O'Donovan, J. B., D. Facey, and W. O'Reilly, The magnetization process in titanomagnetite $\left(\mathrm{Fe}_{2.4} \mathrm{Ti}_{0.6} \mathrm{O}_{4}\right)$ in the $1-30 \mu \mathrm{m}$ particle size range, Geophys. J. Roy. Astronom. Soc., 87, 897-916, 1986.

Orgeira, M. J., A. M. Walther, C. A. Vasquez, I. Di Tommaso, S. Alonso, G. Sherwood, Y. Hu, and J. F. A. Vilas, Mineral magnetic record of paleoclimate variation in loess and paleosol from the Buenos Aires formation (Buenos Aires, Argentina), J. South Am. Earth Sci., 11, 561$570,1998$.

Orgeira, M. J., A. M. Walther, R. Tófalo, C. A. Vásquez, T. Berquó, C. Favier Dubois, and H. Bhonel, Environmental magnetism in paleosoils developed in fluvial and loessic holocene sediments from Chacopampean Plain (Argentina), J. South Am. Earth Sci., 16, 259-274, 2003.

Petrovsky, E., A. Kapicka, N. Jordanova, and L. Boruvka, Magnetic properties of alluvial soils contaminated with lead, zinc and cadmium, $J$. Appl. Geophys., 48, 127-136, 2001.

Pirazzolli, P., Sea-level Changes in the Last 20000 Years, John Wiley and Sons, Chichester, 1996.

Prado, J. L. and M. T. Alberdi, The mammalian record and climatic change over the last 30,000 years in the Pampean Region, Argentina, Quat. Int., 57/58, 165-174, 1999.

Prieto, A. R., Late quaternary vegetational and climatic changes in the Pampa grassland of Argentina, Quat. Res., 45, 73-88, 1996.

Reineck, H. E. and I. B. Singh, Depositional Sedimentary Environments, Springer, Berlin, Heidelberg, New York, 1975.

Russo, A, R. Ferello, and G. Chebli, Llanura Chaco Pampeana, Segundo Simposio de Geología Regional Argentina I, 139-183, Academia Nacional de Ciencias, Córdoba, 1979.

Scasso, R. A. and C. O. Limarino, Petrología y Diagénesis de Rocas Clásticas, Publicación especial no. 1, Asociación Argentina de Sedimentología, Buenos Aires, 1997.

Scharpenseel, H. W., Radiocarbon Dating of Soils-Problems, Troubles, Hopes, in Paleopedology. Origin, Nature and Dating, edited by D. H. Yaalon, pp. 77-88, International Society of Soil Scientists and Israel University Press, Jerusalem, 1971.

Stein, J. K., Organic matter in archeological contexts, in Soils in Archaeology, edited by V. T. Holliday, pp. 193-216, Smithsonian Institution Press, Washington D.C., 1992.

Thompson, R., J. Bloemendal, J. A. Dearing, F. Oldfield, T. A. Rummery, J. C. Stober, and G. M. Turner, Environmental applications of magnetic measurements, Science, 207, 481-486, 2001.

Tonni, E. P., A. L. Cione, and A. J. Figini, Predominance of arid climates indicated by mammals in the pampas of Argentina during the Late Pleistocene and Holocen, Palaeogeograph. Palaeoclimatol. Palaecol., 147, 257-281, 1999.

Tonni, E. P., R. A. Huarte, J. E. Carbonari, and A. J. Figini, New radiocarbon chronology for the Guerrero Member of the Luján Formation (Buenos Aires, Argentina): paleoclimatic significance, Quat. Int., 109110: 45-48, 2003.

Turner, G. M., Environmental applications of magnetic measurements, Science, 207, 481-486, 2001.

Vasquez, C. A., H. G. Nami, and A. E. Rapalini, Magnetic sourcing of obsidians in Southern South America: some successes and doubts, $J$. Archeol. Sci., 28, 613-618, 2001.

Verosub, K. L. and A. P. Roberts, Environmental magnetism: past, present and future, J. Geophys. Res., 100, 2175-2192, 1995.

Weiler, N. E., Cambios relativos del nivel marino ocurridos durante el Pleistoceno Tardío-Holoceno en latitudes medias de la República Argentina, J. Arqueol. Interdiscipl., 143-176, CONICET-PREP, Buenos Aires, 1994.

C. A. Vasquez (e-mail: vasquez@gl.fcen.uba.ar) and H. G. Nami 